Article

\title{
Learner Development of a Morphosyntactic Feature in Argentina: The Case of vos
}

\author{
Rebecca Pozzi (D)
}

Citation: Pozzi, Rebecca. 2021

Learner Development of a Morphosyntactic Feature in Argentina: The Case of vos. Languages 6: 193. https://doi.org/ 10.3390/languages6040193

Academic Editor: Aarnes Gudmestad

Received: 14 June 2021

Accepted: 19 November 2021

Published: 24 November 2021

Publisher's Note: MDPI stays neutral with regard to jurisdictional claims in published maps and institutional affiliations.

Copyright: (c) 2021 by the author Licensee MDPI, Basel, Switzerland. This article is an open access article distributed under the terms and conditions of the Creative Commons Attribution (CC BY) license (https:/ / creativecommons.org/licenses/by/ $4.0 /)$.
Department of World Languages \& Cultures, California State University, Monterey Bay, Seaside, CA 93955, USA; rpozzi@csumb.edu

\begin{abstract}
Students have been found to improve their sociolinguistic competence, particularly regarding the acquisition of dialectal features, while studying abroad. Nevertheless, most of the research on learner development of morphosyntactic features in Spanish-speaking immersion contexts has examined that of variants characteristic of Peninsular Spanish in Spain, namely clitics and the informal second-person plural vosotros. Since the informal second-person singular, vos, is more prevalent than its equivalent, $t u$, in several Latin American countries, learner acquisition of this feature also merits investigation. This article explores second-language learner production of vos among 23 English speakers during a 5-month semester in Buenos Aires, Argentina, a popular study abroad destination. The findings from the multivariate analysis of over 1200 tokens of $t \dot{u}$ and $v o s$ indicate that learners used vos verb forms over $70 \%$ of the time by the end of the sojourn. Factors including social networks, proficiency level, mood, and task significantly influenced this use. Most notably, the stronger the learners' social networks, the more they used vos verb forms and learners with high proficiency levels used these forms more than lower-proficiency learners. This study provides one of the first accounts of the acquisition of a widespread morphosyntactic feature of Latin American Spanish.
\end{abstract}

Keywords: Spanish; sociolinguistic competence; morphosyntactic features; study abroad

\section{Introduction}

Although study abroad (SA) is generally considered an ideal context for achieving proficiency in a foreign language, research on SA suggests that it does not always lead to linguistic improvement (see Collentine and Freed 2004; Lafford and Uscinski 2014; Segalowitz et al. 2004). Learners do tend to make gains, however, with respect to the acquisition of native-like patterns of variation in an SA context, where they encounter input that they are not typically exposed to in the classroom (Regan et al. 2009). Learner production of sociolinguistic variants is important to sociolinguistic competence, which consists of sensitivity to dialects and registers (Bachman 1990) and has been defined as the ability to use target-like patterns of variation (Kennedy 2012). Learners that have acquired sociolinguistic competence are able to adjust their speech based on their interlocutor, geographic location, and context to produce appropriate language that aligns not only with the interlocutor's expectations but also with their own communicative goals (Geeslin and Long 2014). As such, it is widely believed among second language acquisition (SLA) scholars that sociolinguistic competence is necessary for effective communication in the target language (TL).

The majority of existing studies on the acquisition of sociolinguistic competence have explored second-language (L2) development of variation of French or Spanish, while fewer investigations have been conducted on other languages (e.g., Li 2014; Iwasaki 2010). Overall, this research shows that L2 learners incorporate sociolinguistic features into their interlanguage, although they do so less than native speakers (NSs), and their usage patterns vary depending on the features, social factors, and the individual learner.

Of the studies on L2 development of variation in Spanish, a growing number explore L2 acquisition of regional variation. Such investigations on this topic have often examined 
features characteristic of Peninsular Spanish, including clitics (focusing on leísmo, or the use of dative pronouns le(les) as direct object pronouns, see Geeslin et al. 2010; Salgado-Robles 2011) and the second-person plural pronoun vosotros and its corresponding conjugations as opposed to the second-person plural pronoun ustedes and its conjugations (George 2013, 2018; Reynolds-Case 2013; Ringer-Hilfinger 2013). In addition, some studies have compared learner behavior with morphosyntactic features in Spain and Mexico, including the periphrastic, morphological, and present indicative forms of the future tense (Kanwit and Solon 2013) and the preterit versus the present perfect (Geeslin et al. 2013).

Nevertheless, studies on morphosyntactic features used solely in Latin America have been understudied. For example, while most varieties of Spanish distinguish between familiar and polite forms using second-person singular tú (e.g., ¿De dónde eres tú? "Where are you [familiar] from?") and usted (e.g., ¿De dónde es usted? “Where are you [formal] from?"), respectively (see Brown and Gilman 1960), in many parts of Latin America tú is used alongside or is replaced by another familiar form, vos (e.g., ¿De dónde sos vos? "Where are you [informal] from?"). In fact, although vos is more common than tú in many Spanish-speaking countries in Latin America, including two top SA destinations (Costa Rica and Argentina, see (Cameron 2012)), to my knowledge only one study (Hoffman-González 2015) has examined L2 use of this feature in SA. The present study explores L2 use of vos in Argentina, where it is used among NSs across social classes throughout the country in place of tú (Lipski 1994; Schreffler 1994). This study provides one of the first accounts of L2 use of a widespread morphosyntactic feature used in multiple regions in Latin America, vos.

\section{Literature Review}

\subsection{Study Abroad and Language Variation in SLA}

As Lafford and Uscinski (2014) point out in their review of SA and L2 Spanish, some of the most innovative research in this area in recent years has been on the acquisition of sociolinguistic competence. Studies on this topic often employ multivariate analysis tools traditionally used in variationist sociolinguistics to quantitatively measure not only the extent to which L2 learners acquire target-like patterns of variation but also the complex, simultaneous influence of multiple linguistic and social factors on this acquisition (Lafford and Uscinski 2014). This kind of variationist SLA research has focused on forms that are categorical in the TL (Type 1, e.g., (Gudmestad et al. 2021)), as well as forms that are variable (Type 2, e.g., (Escalante 2018)). In Type I variation, learners alternate between target-like (e.g., sé "I know", the target-like first-person, present indicative irregular conjugation of the word saber "to know") and nontarget-like forms (e.g., "sabo, the expected but nontarget-like first-person, present indicative regular conjugation of the verb saber). Type II variation, on the other hand, refers to variation among two or more target-like forms that are present in NS speech (e.g., Yo como la manzana "I eat the apple" versus Como la manzana "(I) eat the apple" (Solon and Pozzi forthcoming)).

The feature under investigation in this study, vos, might be considered a hybrid feature that incorporates aspects of Type 1 and Type 2 variation. This is because although vos is used categorically among NSs in Argentina (Type 1), where the vos pronoun is uniformly used along with the vos verb form, it is new for L2 learners, who presumably learned another categorical form, $t \hat{u}$, in their Spanish classes in the United States, where vos is "sorely missing" from Spanish textbooks (Cameron 2012, p. 72). However, given that vos is a form that varies regionally, it also shares characteristics of Type 2 variation. As such, when addressing an interlocutor informally in Argentina, students might be expected to vary between $t u$ verb forms they likely learned in their previous Spanish classes in the United States (e.g., comes "you eat") and vos verb forms used categorically in Argentina (e.g., comés "you eat").

Results of studies on Type 2 variation show that learner interlanguage is highly systematic and influenced by linguistic and extralinguistic factors; nevertheless, constraints on L2 speech may differ from those that operate on NS speech and might change over time based on proficiency level and contact with NSs (Geeslin and Long 2014). Adopting a 
quantitative variationist methodology from sociolinguistics regarding the measurement of language contact may shed light on the role of social networks in the acquisition of sociolinguistic competence. In their seminal study on the maintenance of phonological features, Milroy and Milroy (1978) developed and used a social network strength scale (SNSS) to quantify participants' social networks. This instrument permitted a quantitative analysis that demonstrated how speakers with the highest SNSS scores used local variable features the most. Since then, the SNSS has been widely used in sociolinguistic work (see Lippi-Green 1989; Lybeck 2002), adapted for use in an SA context (Kennedy 2012; Kennedy Terry 2017), and modified for use in this study in order to better understand the role of social networks in L2 acquisition of vos verb forms.

\subsection{The Acquisition of Morphsyntactic Variation in Spanish during Study Abroad}

A growing body of research on morphosyntactic variation has been conducted in SA contexts. Some of the variable structures examined include subject expression, future-time expression, past-time reference, and object pronouns. Regarding L2 subject expression (i.e., using an overt as opposed to a null subject), Linford (2016) found that while students overgeneralized the use of overt subject pronouns after four months in Santiago, Dominican Republic, they approximated the NS rate of overt subject pronoun use after four months in Madrid, Spain. Moreover, Linford et al. (2018) found that L2 subject pronoun selection approximated that of NSs among high school L2 learners of Spanish studying in Valencia, Spain for 7 weeks and that students who reported more contact with NSs approximated NS norms with respect to form selection.

L2 learners have also moved toward NS norms with respect to variation between the periphrastic future (voy a estudiar mañana "I am going to study tomorrow"), the morphological future (estudiaré mañana "I will study tomorrow") and the present indicative (estudio mañana "I study tomorrow"). Kanwit and Solon (2013) found that learners studying in Mérida, Mexico approached NS norms with respect to the selection of the present indicative and learners studying in Valencia, Spain approximated NS norms regarding the morphological future. Nevertheless, learners in both contexts overestimated NS norms with respect to the periphrastic future.

L2 approximation to NS norms has also been found regarding past-time reference. Variation in the past tense is exhibited in the preference for the present perfect (he bailado "I have danced") over the preterit (bailé "I danced") in some varieties of Peninsular Spanish to refer to events that occurred in the same day. Geeslin et al. (2012) found that high school L2 learners moved toward target-like frequency of present perfect selection rates but did not reach them after 7 weeks in León, Spain. In addition, Geeslin et al. (2013) found that high school students studying in Valencia, Spain moved toward NS norms with respect to the present perfect as opposed to the preterit and high school students studying in San Luís Potosí, Mexico moved toward NS norms regarding the preterit as opposed to the present perfect. However, Whatley's (2013) findings indicate that after a 7-week sojourn in Valencia, Spain, mid-proficiency students moved toward NS norms of preterit, imperfect, and present perfect selection, low-proficiency learners moved toward NS norms only with respect to the imperfect, and high-proficiency learners moved toward NS norms solely regarding the preterit. Whatley (2013) attributed the high-proficiency learners' greater deviation from NS norms to more Spanish instruction in the United States and previous immersion experiences in other Spanish-speaking countries.

Studies on object pronouns have examined the use of leismo, which refers to the use of the dative pronouns le(les) as direct object pronouns and have found that L2 learners move toward but do not reach NS frequency of production. For example, Salgado-Robles (2011) found that university students in Spain approximated NS norms, increasing their use of leísmo in Valladolid, Spain and decreasing it in Sevilla, Spain. Students who had more L2 contact with NSs reached closer approximation to NS norms of leísmo use in both contexts. Moreover, Geeslin et al. (2010) found that high school students first decreased and later increased leísmo selection, approximating NS norms in León, Spain, but not reaching 
them, as their pronoun selection remained significantly different from that of NSs there. Advanced learners in this study selected leismo in a more native-like way than learners of other proficiency levels. Overall, these studies on L2 acquisition of morphosyntactic variation in SA contexts suggest that L2 learners move toward NS norms with respect to frequency of use of these variable features and that proficiency level (Geeslin et al. 2010; Whatley 2013) and NS contact (Linford et al. 2018; Salgado-Robles 2011) may influence this approximation.

\subsection{The Acquisition of Address Forms in Spanish during Study Abroad}

Several studies on L2 acquisition of morphosyntactic features conducted in Spanishspeaking immersion contexts have also focused on L2 development of address forms (George 2013, 2018; Hoffman-González 2015; Reynolds-Case 2013; Ringer-Hilfinger 2013). Such development is especially relevant to L2 acquisition of sociolinguistic and grammatical competence, since verb morphology is determined by address form choice (Kinginger 2008). Research conducted on this topic has examined L2 development of region-specific address forms, including vosotros in Spain (George 2013, 2018; Reynolds-Case 2013; Ringer-Hilfinger 2013) and vos in Argentina (Hoffman-González 2015). Overall, these studies have found an increase in production of these morphosyntactic features during the stay abroad, although the amount of increase varies across features and contexts.

The choice among address forms can be complex for learners of Spanish, particularly for those studying in Spain, for several reasons. First, this choice may be challenging because the second-person plural pronoun vosotros and its corresponding verb forms (e.g., ¿De dónde sois vosotros? "Where are you all [informal] from?") are used there but not in other varieties of Spanish (Hammond 2001). Second, in Spain, vosotros is used frequently to informally address young people, a group of classmates, and students (George 2013), whereas ustedes is generally used to formally address interlocutors (e.g., ¿De dónde son ustedes? "Where are you all [formal] from?"). In contrast, in Latin American Spanish, the second-person plural pronoun ustedes and its corresponding conjugations (e.g., ¿De dónde son ustedes? "Where are you all [informal or formal] from?") are used to address interlocutors in both informal and formal contexts (George 2013). Since students taking Spanish in the United States may have learned to use ustedes (George 2013) and may have seen but not used vosotros in their classes (LeLoup and Schmidt-Rinehart 2018), the vosotros form may be new to students studying in Spain, and they may or may not choose to adopt the form while studying there.

Considering this, Ringer-Hilfinger (2013) examined L2 production of vosotros among 24 students during and after a 4-month semester in Madrid, Spain. She used an instrument that elicited written vosotros commands and found that L2 use of these commands increased while abroad (from $11.1 \%$ at the beginning to $34.7 \%$ at the end and $24.6 \% 4$ months after SA). Higher proficiency level did not correlate with vosotros command use; in fact, beginners used the form more than intermediate and advanced students. Ringer-Hilfinger (2013) suggested that this may have occurred because ustedes had not been established as part of the beginners' interlanguage prior to the sojourn, as was likely the case for higher proficiency learners who had learned the ustedes form in their US Spanish classes. Nevertheless, limitations of this study were related to the instrument used to elicit vosotros, which consisted of three scenarios accompanied by pictures and a verb in the infinitive form. For each scenario, learners were asked to write a command for the group of people in the picture using the verb provided. As such, this instrument did not elicit oral use of vosotros nor did it contain distracters. Moreover, it only elicited six written commands.

Similar to Ringer-Hilfinger (2013), George $(2013,2018)$ investigated learner use of vosotros during a 3-month semester in Spain, but she used an oral discourse completion task (DCT) to elicit 16 tokens of the form in semi-spontaneous speech. Participants were 24 learners who had completed intermediate- or advanced-level coursework prior to the sojourn in Toledo. Results showed that learners increased vosotros use during the sojourn (8.63\% right before leaving for or right after arriving in Spain, 18.22\% mid-semester, and 
$20.96 \%$ at the end of the semester). Despite the significant increase in the use of vosotros by mid-semester, use of the form continued to increase slightly but insignificantly toward the end of SA. Moreover, among the 7 students who produced vosotros the most mid-semester, greater Spanish proficiency had a positive correlation with vosotros attempts; however, this was not the case at the end of the semester. In addition, surprisingly, more contact in Spanish led to fewer vosotros attempts, which George (2013) attributed to possible NS contact with non-Castilian Spanish speakers or insufficiently reported NS contact. Finally, participants who increased vosotros use received explicit instruction on the form, indicating that instruction may facilitate L2 development of this regional pronoun.

Reynolds-Case (2013) also investigated L2 use of vosotros, focusing on 10 intermediate and advanced students who took classes at a language institute in Madrid for four weeks and lived with host families. Instruments included a pre- and post- SA written survey that elicited questions employing the second-person plural form to address different groups of people. Results indicate that during SA, learners increased appropriate use of vosotros and its corresponding verb forms and decreased their use of ustedes. In fact, all students used vosotros at least two times and overall, they produced vosotros appropriately $15 \%$ of the time on the pretest and $65 \%$ of the time on the posttest. Despite this large increase in vosotros production, the instrument was similar to a written DCT, which elicited knowledge about awareness of forms rather than spontaneous oral use of them.

Although these studies on learner production of vosotros yielded an increase in use during SA sojourns of varying lengths, the amount of increase varied, which may be related to differences in proficiency level, task type, and other aspects of research design. With respect to proficiency level, Ringer-Hilfinger (2013) found that beginning learners used vosotros more than intermediate and advanced learners, Reynolds-Case (2013) found that all learners in her study (intermediate and advanced learners) used the form at least twice, and George (2013) found a correlation between vosotros attempts and higher proficiency level only among the greatest vosotros producers mid-semester.

With respect to task type, Reynolds-Case (4-week sojourn (2013)) and Ringer-Hilfinger (4-month sojourn (2013)), who found higher L2 vosotros production (65\% and 34.7\% upon SA conclusion, respectively) than George (3-month sojourn $(2013,2018))$, used a written elicitation task. On the other hand, George $(2013,2018)$, who observed less vosotros use (20.96\% at the end of SA), utilized an oral DCT, which elicited more spontaneous responses. As such, the results of the oral task yielded less vosotros use regardless of length of stay. Moreover, all three of these investigations elicited vosotros through one task in either the written or oral modality and Ringer-Hilfinger's (2013) study only elicited vosotros commands, not present indicative verb forms.

To my knowledge, only one study (Hoffman-González 2015) has explored learner use of vos in SA, focusing on seven learners of Spanish during a semester in Buenos Aires, Argentina. Although findings indicate a minimal increase in vos production during SA (pre-SA production rates of $46.1 \%$ and post-SA rates of $59.6 \%$, for an increase of $13.5 \%$ ), Hoffman-González (2015) attributes this small change over time to tasks that did not successfully elicit the form and the administration of pre-SA interviews up to 5 weeks after the program's start and post-SA interviews up to several weeks following its conclusion. Moreover, one of the vos elicitation tasks was implemented at the end of the interviews, which Hoffman-González (2015) suggested may have resulted in participant fatigue.

Considering the stable, frequent use of vos in Argentina, in the present study I expected to find a significant increase in L2 use of vos during SA in Buenos Aires. Nevertheless, since the previous literature reviewed here suggests that time abroad (see George 2013, 2018; Reynolds-Case 2013; Ringer-Hilfinger 2013), proficiency level (see Geeslin et al. 2010; George 2013; Ringer-Hilfinger 2013; Whatley 2013), social networks (see George 2013; Linford et al. 2018; Salgado-Robles 2011), explicit instruction (see George 2013), as well as task and verbal mood (see George 2013, 2018; Reynolds-Case 2013; Ringer-Hilfinger 2013), may be important in L2 use of address forms during SA, these factors were expected to affect vos production. This study sought to answer the following research questions: To 
what extent do NSs of English produce vos verb forms after 2.5 and 5 months studying abroad in Buenos Aires, Argentina? What linguistic and extralinguistic factors significantly impact the production of vos verb forms?

\section{Methodology}

\subsection{Participants}

Participants included 23 L2 learners (19 females and 4 males) of Spanish from the United States who resided with host families, in apartments, or in university residences and studied at different universities across Buenos Aires for 5 months. Most students had little or no contact with Argentine Spanish prior to the sojourn (with the exception of Camille, for example, who had learned about Buenos Aires phonological features in a Hispanic Linguistics course prior to the sojourn). Their self-reported course placements (based on program-specific multiple-choice exams or writing assessments) varied, as three were placed in beginning courses, six took intermediate classes, and 14 were in the advanced track. More information about the participants (whose names are pseudonyms) can be seen in Table 1.

Table 1. Participant Characteristics.

\begin{tabular}{|c|c|c|c|c|}
\hline Speaker & Age & Gender & Proficiency & ${ }^{*}$ Living Situation \\
\hline Brittany & 22 & $\mathrm{~F}$ & Advanced & Host family/apartment alone \\
\hline Ryan & 22 & M & Advanced & Apartment alone \\
\hline Kelly & 23 & $\mathrm{~F}$ & Advanced & Apartment alone \\
\hline Mary & 20 & $\mathrm{~F}$ & Advanced & Host family/apartment alone \\
\hline Andrea & 22 & $\mathrm{~F}$ & Advanced & Apartment with Argentines \\
\hline Emily & 19 & $\mathrm{~F}$ & Advanced & Host family \\
\hline Kerry & 20 & $\mathrm{~F}$ & Advanced & Host family \\
\hline Jenny & 22 & $\mathrm{~F}$ & Advanced & Apartment with Argentines \\
\hline Amy & 23 & $\mathrm{~F}$ & Advanced & Apartment alone \\
\hline Valerie & 22 & $\mathrm{~F}$ & Advanced & Host family \\
\hline Erin & 21 & $\mathrm{~F}$ & Advanced & Host family \\
\hline Tyler & 19 & M & Advanced & Host family \\
\hline Alicia & 19 & $\mathrm{~F}$ & Advanced & Host family \\
\hline Alison & 20 & $\mathrm{~F}$ & Advanced & Host family/dorm-style residence \\
\hline Mariah & 19 & $\mathrm{~F}$ & Intermediate & Host family \\
\hline Andrew & 26 & M & Intermediate & Dorm-style residence / apartment alone \\
\hline Eddie & 20 & M & Intermediate & Host family \\
\hline Melanie & 20 & $\mathrm{~F}$ & Intermediate & Host family \\
\hline Camille & 21 & $\mathrm{~F}$ & Intermediate & Host family \\
\hline Kathryn & 20 & $\mathrm{~F}$ & Beginning & Host family/Dorm-style residence \\
\hline Chelsea & 20 & $\mathrm{~F}$ & Beginning & Host family \\
\hline Kim & 20 & $\mathrm{~F}$ & Beginning & Host family \\
\hline Julia & 20 & $\mathrm{~F}$ & Beginning & Dorm-style residence \\
\hline
\end{tabular}

* Those who have more than one living situation listed changed their place of residence during SA.

\subsection{Materials}

Several procedures were followed in order to collect data from participants via Skype at three data-collection times: prior to or right after students arrived in Buenos Aires, halfway through SA, and at the end or immediately following their return home. During the approximately hour-long Skype calls that took place with each participant at each data-collection time, participants first spoke for approximately $20 \mathrm{~min}$ in Spanish with me (a non-native speaker of Buenos Aires Spanish) about their experiences abroad as well as their lives prior to, during, and/or following the sojourn. I used vos with participants for the initial conversations at each data-collection time; however, I resorted to using the tú form in data-collection 1 when participants had trouble understanding the vos form. After this initial conversation at each data-collection time, in order to elicit use of vos, an oral DCT (based on (George 2013)) and two role plays (based on Kinginger 2008; Villareal 2014) 
were conducted. Furthermore, a background questionnaire was administered before the sojourn, and a semi-structured interview and a SNSS (Kennedy 2012; Kennedy Terry 2017; Milroy and Milroy 1978, see Appendix C) were conducted orally at each data-collection time to better understand participants' experiences and social networks.

The oral DCT (see Appendix A) was modeled after the one used by George (2013) to elicit use of vosotros. It consisted of 4 scenarios that included 28 situations in English and elicited responses in Spanish. A total of 16 of those situations aimed for students to use vos and 12 of those situations sought the use of other verb forms such as the ustedes form, the first person in the present tense, or the third person in the present tense. Of those 16 items that elicited vos forms, 11 elicited the present indicative and 5 elicited commands.

The role plays (see Appendix B) intended to elicit tokens of vos without revealing this to participants so that their production of the form would not be affected (see Labov's Observer's Paradox (Labov 1972)). The role play scenarios were designed to have participants gather information about their interlocutors, encouraging them to use an address form pronoun to do so (Villareal 2014). Students were provided with detailed instructions regarding the role play scenarios, which they were able to read silently in English and refer to during the role plays in Spanish with me. The first role play scenario was based on one used by Kinginger (2008) to elicit an informal invitation in which one friend calls another and invites her to a party. The second was based on a role play used by Villareal (2014) to elicit an informal request in which an unfamiliar classmate asks another for his notes. In response to George's (2013) suggestion, the role plays aimed to elicit learner use of vos in spontaneous speech.

The SNSS was used in order to obtain a quantitative measure of the quantity and quality of students' interactions with NSs in the host community (Kennedy Terry 2017, see Appendix C). This instrument was chosen because it elicits information regarding the NS interlocutors with whom students interact and the activities in which they participate during SA.

\subsection{Analysis}

Tokens of vos were obtained from the oral DCT and the role plays. First, I transcribed participants' responses from these two sections of the recordings. Then, I marked each verb that was clearly in the $t u$ or vos form without taking into consideration the use of an overt pronoun. See Table 2 for a summary of the differences in $t u ́$ and vos verb conjugations in the present tense of the indicative mood.

Table 2. Tú versus vos conjugations in the present indicative.

\begin{tabular}{ccccc}
\hline Verb Ending & Infinitive & Translation & Tú Conjugation & $\begin{array}{c}\text { Vos } \\
\text { Conjugation }\end{array}$ \\
\hline -AR & Cantar & To sing & Cantas & Cantás \\
\hline -ER & Querer & To want & Quieres & Querés \\
\hline -IR & Vivir & To live & Vives & Vivís \\
\hline
\end{tabular}

As seen in Table 2, the penultimate syllable receives the stress in the $t \dot{u}$ form, and the final syllable receives it in the vos form. Moreover, while stem changes occur in the tú form as in tú quieres ("you want"), they do not occur in the vos form, as in vos querés ("you want"). Finally, there are two irregular verbs in the present indicative of the vos form: ser meaning "to be" (vos sos "you are") and ir meaning "to go" (vos vas, "you go"). See Table 3 for a summary of the differences in $t u$ and vos conjugations in affirmative commands. 
Table 3. Tú versus vos conjugations in affirmative commands.

\begin{tabular}{ccccc}
\hline Verb Ending & Infinitive & Translation & Tú Conjugation & $\begin{array}{c}\text { Vos } \\
\text { Conjugation }\end{array}$ \\
\hline -AR & Escuchar & To listen to & Escucha & Escuchá \\
\hline -ER & Volver & To return & Vuelve & Volvé \\
\hline -IR & Escribir & To write & Escribe & Escribí \\
\hline
\end{tabular}

As seen in Table 3, similar to the present indicative, in affirmative commands the penultimate syllable receives the stress in the tú form and the final syllable receives it in the vos form. Moreover, stem changes occur in the tú form as in vuelve ("return") but not in the vos form, as in volvé ("return"). As outlined in Tables 2 and 3, the vos pronoun is used with its corresponding vos conjugations in the present indicative and affirmative commands in Argentina. However, in some parts of Latin America the vos pronoun is used with tú conjugations and in other parts the tú pronoun is used with vos conjugations.

Despite the exclusive use of vos and its corresponding conjugations in Argentina, some verbs are conjugated the same way in the tú and vos forms (e.g., estás "you are" and vas "you go"). These verbs were not counted in the analysis because it was unclear which form participants were attempting to use in these instances. In addition, disjunctive pronouns as in Quiero hablar con vos ("I want to talk to you") were not counted because they are pronouns, not verb forms. Furthermore, indirect object pronouns (as in quiero escucharte "I want to listen to you") and possessive pronouns (as in tu casa "your house") were not counted because these pronouns are the same in the tú and vos forms and they are not verb forms. Following Kinginger (2008), the following methodology was used to determine vos tokens in the oral DCT and the role plays:

1. All cases in which vos was clearly indicated by verb morphology were counted. These included:

a. Verbs clearly in the vos form in the present tense as in ¿Qué planes tenés? ("What plans do you have?")

b. Verbs clearly in the vos command form as in Vení ("Come");

2. In cases in which the same syntactic slot involved repetition of the same form, only one instance of vos was counted, as in ¿Querés ... querés ir? ("Do you want ... do you want to go?");

3. In cases in which repair within the same syntactic slot involved a switch from one form to another, only one instance of the last form used was counted, as it was presumably students' final choice or correction regarding the form they intended to use. For example, in ¿Qué quieres [tú form] ... que querés [vos form] hacer? ("What do you want... what do you want to do?"), one instance of a vos verb form was counted;

4. In cases in which a vos pronoun was used with a $t \dot{u}$ verb form (there were four total cases of this from two different speakers), as in vos vives ("you live"), the instance was removed from the analysis since it was unclear whether the participant was attempting to use tú or vos.;

5. When participants used a vos pronoun and clearly attempted to use a vos verb form but did so incorrectly, these instances were counted as uses of vos. There were three total incorrect vos attempts like this from two different speakers in which the student used the vos pronoun and a verb (e.g., vos querís "you want") that was more similar to the vos form (e.g., vos querés, "you want") than the tú form (e.g., tú quieres, "you want"). Regarding the SNSS analysis, participants orally provided the names, origins, and ages of the NSs with whom they had spoken in Spanish for $30 \mathrm{~min}$ or more in the last 2 weeks, the number of hours they spoke and the topics they discussed, how they knew the NSs, and the activities they did together. Participants were also asked to indicate which NSs knew each other and how. In terms of quantifying this information, one point was given for each NS from Buenos Aires, one point was awarded for each hour per week 
participants spoke in Spanish with each NS from Buenos Aires, one point was assigned for each topic discussed with each NS from Buenos Aires, one point was allowed for each activity completed with each NS from Buenos Aires, and one point was allocated for each connection between NSs on the list. Based on this point system, an SNSS score (Low, 0-19 points; Mid, 20-39 points; or High, 40 points and up) was calculated for each participant at each data-collection time and included in the analysis. ${ }^{1}$

More than 1200 tokens of $t u$ and vos verb forms were analyzed using a mixed-effects model, Rbrul (Johnson 2009), to examine the role of several factors in L2 vos verb form production. The analysis performed was the use of vos versus $t \dot{u}$ verb forms in the present indicative and affirmative commands since those are the main forms in which $t u$ and vos conjugations differ. Data from data-collection 1 were not included in the regression analysis because all participants categorically produced tú verb forms, and 2 speakers (Brittany and Ryan, see Table 4) were removed from the analysis in data-collection 3, when they categorically used vos verb forms. These data were removed because the goal of the study was to examine patterns of variation in the use of vos. As such, when speakers use one of the variants of the variable under investigation categorically, they do not vary. This is relevant to studies that explore features that speakers are acquiring because the aim is to understand which factors influence the use of the feature during the process of acquisition. When learners are found to use one variant categorically or once they have fully acquired one variant, their data is not relevant to determine the factors that impact variation.

Drawing on previous literature, the linguistic factor considered in the multivariate analysis was mood (indicative or imperative, see (George 2013, 2018)), and the extralinguistic factors were task (oral DCT or role plays, see (George 2013, 2018)), SNSS (high, mid, low; see (Kennedy 2012; Kennedy Terry 2017)), proficiency level (beginner, intermediate, advanced; see (Ringer-Hilfinger 2013)), explicit instruction (yes or no, see George 2013), and data-collection time (1, 2, 3; see (George 2013, 2018)). Gender was not considered since only 4 of the 23 participants were male. Speaker was included as a random effect.

\section{Results}

Findings indicate that SA participants made great gains in vos production by midsemester and continued to increase that use, albeit less dramatically, in the second half of the program. When including categorical vos producers, participants used vos $0 \%$ of the time pre-SA, $65.3 \%$ of the time mid-program, and $70.4 \%$ of the time post-SA. The data in Table 4 come from the tokens that were recorded during the oral DCT and the role plays. Prior to excluding data from the analysis, a total of 1279 tokens of $t u$ and vos verb forms were recorded. After removing data-collection 1 data (participants produced tú verb forms categorically at data-collection 1) and data from categorical vos users (Brittany and Ryan, who categorically produced vos verb forms at data-collection 3), 829 morphosyntactic tokens (286 tokens of $t u$ verb forms and 543 tokens of vos verb forms) were analyzed using Rbrul. ${ }^{2}$

Table 4. Total Tokens by Speaker, Data-collection time, Vos Versus Tú Verb Form Analysis.

\begin{tabular}{|c|c|c|c|c|c|c|c|c|}
\hline \multirow[t]{2}{*}{ Speaker } & \multicolumn{2}{|c|}{ Data-Collection 2} & \multicolumn{2}{|c|}{ Data-Collection 3} & \multicolumn{2}{|c|}{$\begin{array}{c}\text { Total (No Categorical } \\
\text { Speakers) }\end{array}$} & \multicolumn{2}{|c|}{ Total (All) } \\
\hline & $T u ́$ & vos & $t u ́$ & vos & $t u ́$ & vos & $t u ́$ & vos \\
\hline \multicolumn{9}{|c|}{ Advanced speakers } \\
\hline Brittany & 1 & 21 & 0 & 19 & 1 & 21 & 1 & 40 \\
\hline Ryan & 1 & 23 & 0 & 24 & 1 & 23 & 1 & 47 \\
\hline Kelly & 1 & 22 & 2 & 22 & 3 & 44 & 3 & 44 \\
\hline Mary & 5 & 18 & 3 & 18 & 8 & 36 & 8 & 36 \\
\hline
\end{tabular}


Table 4. Cont.

\begin{tabular}{|c|c|c|c|c|c|c|c|c|}
\hline \multirow[t]{2}{*}{ Speaker } & \multicolumn{2}{|c|}{ Data-Collection 2} & \multicolumn{2}{|c|}{ Data-Collection 3} & \multicolumn{2}{|c|}{$\begin{array}{c}\text { Total (No Categorical } \\
\text { Speakers) }\end{array}$} & \multicolumn{2}{|c|}{ Total (All) } \\
\hline & Tú & vos & $t u ́$ & vos & $t u ́$ & vos & tú & vos \\
\hline \multicolumn{9}{|c|}{ Advanced speakers } \\
\hline Andrea & - & - & 1 & 20 & 1 & 20 & 1 & 20 \\
\hline Emily & - & - & 1 & 27 & 1 & 27 & 1 & 27 \\
\hline Kerry & 2 & 17 & 2 & 16 & 4 & 33 & 4 & 33 \\
\hline Jenny & 5 & 10 & 4 & 18 & 9 & 28 & 9 & 28 \\
\hline Amy & 9 & 14 & 12 & 9 & 21 & 23 & 21 & 23 \\
\hline Valerie & 7 & 9 & 6 & 13 & 13 & 22 & 13 & 22 \\
\hline Erin & - & - & 3 & 17 & 3 & 17 & 3 & 17 \\
\hline Tyler & 13 & 12 & 9 & 13 & 22 & 25 & 22 & 25 \\
\hline Alicia & 8 & 13 & 4 & 19 & 12 & 32 & 12 & 32 \\
\hline Alison & 4 & 13 & 8 & 12 & 12 & 25 & 12 & 25 \\
\hline \multicolumn{9}{|c|}{ Intermediate speakers } \\
\hline Mariah & 1 & 17 & 6 & 21 & 7 & 38 & 7 & 38 \\
\hline Andrew & 11 & 14 & 6 & 15 & 17 & 29 & 17 & 29 \\
\hline Eddie & 15 & 2 & 7 & 13 & 22 & 15 & 22 & 15 \\
\hline Melanie & 11 & 7 & 11 & 5 & 22 & 12 & 22 & 12 \\
\hline Camille & 12 & 1 & 19 & 5 & 31 & 6 & 31 & 6 \\
\hline \multicolumn{9}{|c|}{ Beginning speakers } \\
\hline Kathryn & 5 & 15 & 5 & 16 & 10 & 31 & 10 & 31 \\
\hline Chelsea & 1 & 17 & 8 & 7 & 23 & 11 & 23 & 11 \\
\hline Kim & 9 & 5 & 8 & 4 & 17 & 9 & 17 & 9 \\
\hline Julia & 15 & 6 & 11 & 10 & 26 & 16 & 26 & 16 \\
\hline $\begin{array}{l}\text { Total (no } \\
\text { categorical } \\
\text { speakers) }\end{array}$ & 136 & 256 & 136 & 281 & 286 & 543 & 272 & 580 \\
\hline Total (all) & 136 & 256 & 136 & 324 & & & & \\
\hline
\end{tabular}

As shown in Table 4, there were 6 participants who produced tú verb forms more than vos verb forms in data-collection 3. Three of these speakers were beginning learners (Chelsea, Kim, and Julia), two were intermediate learners (Melanie and Camille) and one was an advanced learner (Amy). Four had low scores on the SNSS at data-collection 2 and 3 (Chelsea, Kim, Julia, and Camille), one had a low SNSS score at data-collection 1 and a mid SNSS score at data-collection 2 (Melanie), and one had a mid SNSS score at data-collection 2 and 3 (Amy). In addition, the two participants who used vos categorically during datacollection 3 (Brittany and Ryan) were advanced learners with high SNSS scores.

Table 5 summarizes the results of the vos analysis that explored the use of vos verb forms versus tú verb forms. In the table, the column furthest to the right provides the factor weight for each factor in the factor group. This weight ranges from 0 to 1 and indicates the extent of the influence of each factor in relation to the other factors in the same factor group on the use of vos. Weights greater than 0.50 show that the factor positively influences the production of vos verb forms. Table 5 shows only the factor groups that were found to be significant at $p<0.05$ for the vos versus tú analysis: task $(p=0.0127)$, mood $(p<0.001)$, SNSS $(p=0.00204)$, and proficiency level $(p=0.0383)$. Since explicit instruction and data-collection time were not found to be significant, they do not appear in the table. 
Potential reasons for their lack of significance are discussed in the Discussion section. The 829 tokens accounted for in Table 5 are the same number of tokens accounted for in the vos analysis shown in Table 4, after removing the two participants who produced vos verb forms categorically at data-collection 3 .

Table 5. Vos Verb Forms Versus Tú Verb Forms (application value = vos verb forms).

\begin{tabular}{cccccc}
\hline $\begin{array}{c}\text { Factor } \\
\text { Group }\end{array}$ & Factor & Log-Odds & N & \% Vos & Weight \\
\hline Task & Oral DCT & 0.236 & 514 & 65.8 & 0.545 \\
& Role plays & -0.236 & 315 & 65.1 & 0.427 \\
Mood & Present indicative & 0.589 & 652 & 68.9 & 0.563 \\
& Imperative & -0.589 & 177 & 53.1 & 0.284 \\
SNSS & High & 1.154 & 158 & 99.1 & 0.793 \\
& Mid & -0.210 & 403 & 70.2 & 0.494 \\
Proficiency & Low & -0.944 & 268 & 43.3 & 0.319 \\
& Advanced & 0.681 & 487 & 77.2 & 0.606 \\
& Beginning & -0.180 & 143 & 46.9 & 0.394 \\
Total & Intermediate & -0.500 & 199 & 50.3 & 0.321 \\
& Input & & 829 & 65.5 & 0.713 \\
\hline
\end{tabular}

As seen in the task factor group in Table 5, vos verb forms were slightly favored in the oral DCT with a factor weight of 0.545 and slightly disfavored in the role plays with a factor weight of 0.427 . Mood also significantly constrained learner use of vos. Participants used vos verb forms more in the present indicative (with a factor weight of 0.563 ) than the imperative (with a factor weight of 0.284). Regarding the SNSS factor group, participants with high scores on the SNSS produced vos verb forms $99.1 \%$ of the time, with a factor weight of 0.793 . Those with mid SNSS scores used vos verb forms $70.2 \%$ of the time, with a factor weight of 0.494 . Finally, participants with low SNSS scores used vos verb forms $43.3 \%$ of the time, with a factor weight of 0.319 . These results indicate that the greater the social networks created by the learners in the host community, the more they used vos verb forms. With respect to the proficiency level factor group, learners with advanced proficiency levels favored the use of vos verb forms the most, with a factor weight of 0.606. Participants with beginning and intermediate proficiency levels disfavored the use of vos verb forms. Judging by the factor weights presented in Table 5, the strongest predictor of the use of vos was social networks (with a high SNSS factor weight of 0.793 ), followed by proficiency level (with an advanced proficiency level factor weight of 0.606). Finally, speaker was included as a random effect (intercept $=0.453$ ), with weights ranging from 0.269 (in which learners produced vos $52.3 \%$ of the time) to 0.785 (in which learners produced it $84.4 \%$ of the time).

Table 6 shows the results of a cross-tabulation analysis between individual speaker, proficiency level, and SNSS. As seen in the first group of advanced participants at the top of Table 6, the five participants who had high SNSS scores also had advanced proficiency in Spanish. These results suggest that only advanced learners were able to create large/strong enough social networks with NSs to earn high SNSS scores. Furthermore, vos verb forms were used the most by learners with advanced proficiency, followed by those with beginning proficiency, and finally those with intermediate proficiency. Beginning learners may have produced vos more than intermediate learners because all four beginning learners received explicit instruction on vos during SA while only some intermediate learners did. Nonetheless, explicit instruction was not found to be a significant predictor of vos production in the analysis. 
Table 6. Vos Production by Proficiency Level, SNSS.

\begin{tabular}{cccc}
\hline Speaker & $\begin{array}{c}\text { Total \% vos } \\
\text { Production }\end{array}$ & Proficiency Level & $*$ SNSS \\
\hline Brittany & 95.5 & Advanced & High \\
Ryan & 95.8 & Advanced & High \\
Kelly & 93.6 & Advanced & High \\
Mary & 81.1 & Advanced & High \\
Andrea & 95.2 & Advanced & High \\
\hline Emily & 96.4 & Advanced & Mid \\
Kerry & 89.2 & Advanced & Mid \\
Jenny & 75.7 & Advanced & Mid \\
Amy & 52.3 & Advanced & Mid \\
Valerie & 62.9 & Advanced & Mid \\
Erin & 85 & Advanced & Mid \\
Tyler & 53.2 & Advanced & Low, Mid \\
Alicia & 72.7 & Advanced & Low, Mid \\
Alison & 67.6 & Advanced & Low \\
\hline Mariah & 84.4 & Intermediate & Mid \\
Andrew & 63.0 & Intermediate & Mid \\
Eddie & 40.5 & Intermediate & Low, Mid \\
Melanie & 35.3 & Intermediate & Low, Mid \\
Camille & 16.2 & Intermediate & Low \\
\hline Kathryn & 75.6 & Beginning & Low, Mid \\
Chelsea & 32.4 & Beginning & Low \\
Kim & 34.6 & Beginning & Low \\
Julia & 38.1 & Beginning & Low \\
\hline
\end{tabular}

*When two SNSS scores are displayed, the first is from data-collection 2 and the second is from data-collection 3. When only one SNSS score is displayed, the SNSS score at data-collection 2 and 3 was in the same range.

\section{Discussion}

The first research question this study sought to answer was: to what extent do NSs of English produce vos verb forms after 2.5 and 5 months studying abroad in Buenos Aires, Argentina? Overall, results including all participants demonstrate that they made gains in production of this morphosyntactic feature, using vos $65.3 \%$ of the time by mid-semester and $70.4 \%$ of the time by the end of SA. These results are similar but slightly higher than those found in previous research. In particular, Hoffman-González (2015) found that during her post-SA interviews learners produced vos pronouns and verb forms $59.6 \%$ of the time, as opposed to the present study's finding of post-SA vos verb form production $70.4 \%$ of the time. The slightly lower production of vos in Hoffman-González (2015) could be due to the implementation of post-SA interviews up to several weeks following participants' return to the United States.

In addition, L2 learners studying in Argentina appear to adopt vos more than L2 learners studying in Spain adopt other morphosyntactic features (see George 2013, 2018; Reynolds-Case 2013; Ringer-Hilfinger 2013). In particular, L2 vos production in Argentina seems to be higher than L2 vosotros production in Spain, especially when comparing only the studies that elicited features in the oral modality in which participants spent similar amounts of time abroad. For example, participants in the present study used vos $65 \%$ of the time at data-collection 2 after 2.5 months in Argentina and participants in the study conducted by George $(2013,2018)$ used vosotros $21 \%$ of the time after 3 months studying in Spain. This may be because some students of Spanish learn to address groups of people using ustedes in formal and informal contexts in their Spanish classes in the United States in which vosotros is often acknowledged in textbooks but not explicitly taught in class (LeLoup and Schmidt-Rinehart 2018). Therefore, these students may struggle to use vosotros to address groups in informal contexts and ustedes to address groups in formal contexts in Spain. Vos, on the other hand, is used to address one interlocutor informally 
instead of tú in Argentina. Since vos is used in a growing number of situations in which usted was previously employed in the country (e.g., service encounters, (Kapovic 2007)), students are increasingly exposed to vos while studying there. Thus, it is possible that the range of contexts in which vos is used in Argentina may facilitate L2 development of this form.

The second research question this study sought to answer was: what linguistic and extralinguistic factors significantly impact the production of vos? The strongest predictor of use of vos was social networks. The greater the social networks of the L2 learners, the more they used vos. In contrast to George (2013), who found that more contact with Spanish led to less vosotros attempts, the present study found that there was a significant correlation among social networks with NSs and L2 vos production. These results are similar to the findings that students who had more contact with NSs approximated NS norms with respect to subject pronoun selection (Linford et al. 2018) and use of leismo (Salgado-Robles 2011) in Spanish. These findings also align with the positive correlation between social networks with NSs and target-like phonological production in French (Kennedy 2012).

This study also found that proficiency level was a significant predictor of vos production among L2 learners, and only advanced learners were able to create social networks large/strong enough to correspond to high scores on the SNSS. Moreover, advanced learners used vos the most, followed by beginning learners, and, lastly, intermediate learners. Since all four beginning learners received explicit instruction on the form and several intermediate learners did not, explicit instruction may have been related to the greater vos production by beginning learners. Nevertheless, explicit instruction did not have a significant effect on L2 production of vos in the present study.

The findings regarding the role of proficiency level in L2 vos production are unsurprising when considering the importance of proficiency in the acquisition of sociolinguistic competence in previous literature (e.g., Geeslin et al. 2010; Sax 2003). Nonetheless, these results differ from prior work that explored the relationship among proficiency and vosotros production (Ringer-Hilfinger 2013), which found that higher proficiency did not influence learner use of vosotros commands. Still, the findings of Ringer-Hilfinger's (2013) vosotros study may have been affected by the written mode of the elicitation task (which can yield information about L2 awareness of forms rather than spontaneous oral use of them) and by the elicitation of vosotros in commands, but not in the present indicative.

Mood and task also significantly influenced L2 use of vos in the present study. Regarding mood, L2 learners used vos significantly more in the present indicative than in the imperative. This is in line with previous research on vosotros (George 2013, 2018), which also found that use of the feature was favored in questions (the present indicative) as opposed to commands. With respect to task, participants used vos significantly more during the oral DCT than during the role plays. It seems possible that learners used vos less in the role plays (more spontaneous speech), during which the tú form they originally learned in their Spanish classes in the United States may have been more likely to surface. As suggested by Tarone (1985), this more meaning-focused task may have promoted more accurate L2 speech and less attention to form, which yielded less use of vos.

Factors that did not significantly influence vos verb form use in this study included explicit instruction and data-collection time. The latter result may be because the vos analysis did not include data-collection 1 in which learners produced tú forms categorically. Instead, the vos analysis took into consideration data-collection 2 (in which participants produced vos verb forms $65.3 \%$ of the time) and data-collection 3 (in which participants produced vos verb forms $70.4 \%$ of the time). Thus, the increase in vos production between data-collection 2 (2.5 months into SA) and data-collection 3 (after 5 months in Buenos Aires) was $5.1 \%$, which was not enough to reach significance. This pattern of a large increase in morphosyntactic feature production between data-collection 1 and 2 and then a smaller increase between data-collection 2 and 3 is consistent with previous research on L2 acquisition of vosotros in Spain (George 2013,2018), which found a significant increase in 
the use of vosotros between pre-SA data collection (during which participants produced vosotros $9 \%$ of the time) and mid-SA data collection (during which they produced it $18 \%$ of the time), but not between mid-SA data collection and post-SA data collection (during which they produced it $20 \%$ of the time).

\section{Conclusions}

Overall, the results of this study indicate that participants increased their use of vos throughout the semester in Buenos Aires, Argentina, reaching vos production over 70\% of the time by the end of SA. Social networks and proficiency level were the strongest predictors of L2 use of vos, followed by mood and task. In fact, the two speakers who categorically produced vos verb forms in data-collection 3 were advanced learners with high SNSS scores, which indicates that advanced proficiency and large/strong social networks may be important factors in the acquisition of vos.

There were some limitations to this study. First, Skype was used to collect data. Although participants were asked to find a quiet space with fast Internet and to use earbuds with a microphone, occasionally there was background noise or an interruption in the connection. Nevertheless, these challenges did not result in difficulty determining participants' verb form production. Other limitations to this study are the inclusion of self-reported information about social networks used to calculate SNSS scores and the determination of proficiency level based on students' placement in beginning, intermediate, and advanced courses in their SA programs. Future studies might incorporate pre- and post-SA proficiency tests, examine L2 use of vos in naturalistic interactions, utilize a mixedmethods approach to complement quantitative results with qualitative ones, or examine L2 vos production in other Spanish-speaking communities in which vos is used.

Funding: This research was funded by a Language Learning Dissertation Grant.

Institutional Review Board Statement: The study was conducted according to the guidelines of the Declaration of Helsinki, and approved by the Institutional Review Board (or Ethics Committee) of UC Davis (IRB ID 500947-3 and 14 May 2015).

Informed Consent Statement: Informed consent was obtained from all subjects involved in the study.

Data Availability Statement: The data presented in this study are available on request from the corresponding author. The data are not publicly available due to privacy and ethical restrictions.

Conflicts of Interest: The authors declare no conflict of interest.

\section{Appendix A}

Oral Discourse Completion Task (DCT), (Adapted from (George 2013))

Situation A: You are eating lunch at the university cafeteria with a new Argentine friend, Marco.

1. Marco arrives and sits down. He says "hola, cómo estás?". How do you respond to him?

2. You want to order pizza but you think it might be too much food for you and you ask Marco if he wants to share with you. What do you say to him?

3. You ask Marco what his plans are for the long weekend after your classes let out on Thursday. What do you say to him?

4. Marco sees one of his friends walk into the cafeteria. She walks over to you and Marco and she asks you what your name is. You answer her and you also want to know her name. What do you say to her?

5. You ask her where she is from. What do you say to her?

6. You ask her what she studies. What do you say to her?

7. You ask her where she lives. What do you say to her?

8. You ask her if she has brothers/sisters. What do you say to her?

9. You seem to get along well so you ask her if she wants to go to the movies with you and some friends tomorrow night. What do you say to her? 
Situation B: You are volunteering at a community center in Argentina. You are helping with the after school program where you must lead elementary school-aged children in various activities.

1. When you walk into the community center the kids are all running around and you need them to sit down. What do you say to the children in order to get them to sit down?

2. One of the students, Manolo, asks you if he can go to the bathroom. How do you respond to him?

3. You need to get the attention of all of the students in order to start the next activity. What do you say to them?

4. Some of the parents arrive to pick up their children. How do you greet them?

5. One of the mothers asks you what you think of her student, who happens to be an excellent participant in the activities and always listens. What do you tell her?

6. What do you say as the kids and their parents are leaving?

Situation C: You are helping with the after school program in Argentina where you are a tutor.

1. When you walk into the after school program the kid you are supposed to work with, Santiago, is playing across the room and you tell him to come. What do you say to him?

2. You tell him to sit down so that you can start the days' activities. What do you say to him?

3. You ask Santiago what he wants to do today. What do you say to him?

4. You ask Santiago if he has homework. What do you say to him?

5. Santiago says the dog ate his homework. You tell him to tell you the truth. What do you say to him?

6. Santiago was just joking. He takes out his homework. You tell him to write his name. What do you say to him?

7. In order to complete the homework he needs his textbook. You tell him to open his book. What do you say to him?

Situation D: You are eating lunch in Argentina with some new Argentine friends you made while staying in a hostel. They are traveling around a bit and they decided to visit you.

1. You ask your new Argentine friends what they are going to do after eating lunch. What do you say to them?

2. You ask your friends what they are going to drink, in order to help you decide. What do you say to them?

3. The waiter comes over and asks what you would like to drink. What do you say to him?

4. Two of your friends went out with you the night before, but you had to go home before they did. You ask them what they did the rest of the night and when got back to their hostel. What do you say to them?

5. One of your Argentine friends from school comes up to you and greets you in Spanish. What do you say to him?

6. You are ready to leave, because your class starts soon. What do you say to your friends?

\section{Appendix B}

Role Plays (Adapted from (Kinginger 2008; Villareal 2014)).

Role Play 1-Invitation: After a few weeks in Argentina, you call an Argentine friend whom you met a few weeks ago. This friend is 20 years old. You ask her how she's doing and how her week is going. You then ask her if she has plans for the weekend. You invite her to a party at your new place on Saturday evening, you tell her who will be there, and you ask her to bring a couple of her friends and something to eat or drink. 
Role Play 2-Request: It is your second week of your program in Argentina. You decided to take some classes at the university and you accidentally missed one of your classes yesterday. In the library, you recognize one of your classmates, a male your age whom you have not yet met, and you decide to ask him for yesterday's class notes. However, since you do not yet know him, you decide you should chat with him and get to know him a little bit before asking a favor of him. You should at least find out his name, where he is from, what he studies, and a little about his interests (music, books, or sports, etc.) and/or he does in his free time. Ask him whether or not he was in class yesterday (and if he took notes) before you finally ask him for yesterday's notes.

\section{Appendix C}

Social Network Strength Scale (adapted from (Kennedy 2012)).

Name: Date:

(1) List each native Spanish-speaking person with whom you have maintained at least a 30-min conversation in Spanish over the last couple of weeks. List the number of hours per week (if you spent time with two+ people at the same time, include the number of hours next to one name), your relationship to this person (e.g., host mom, conversation partner), where each person is from (country, city, neighborhood), and their approximate age.

(2) Check and/or list all activities in which you participated with this person (e.g., sharing a meal/drink, taking a trip, exercising, celebrating an occasion, playing a sport/board game/cards, going to an event/bar/club) and all of the topic(s) you discussed with this person (e.g., culture, current events, politics, sports, music, movies, TV, problems, plans, school, daily life).

Table A1. Social Network Strength Scale.

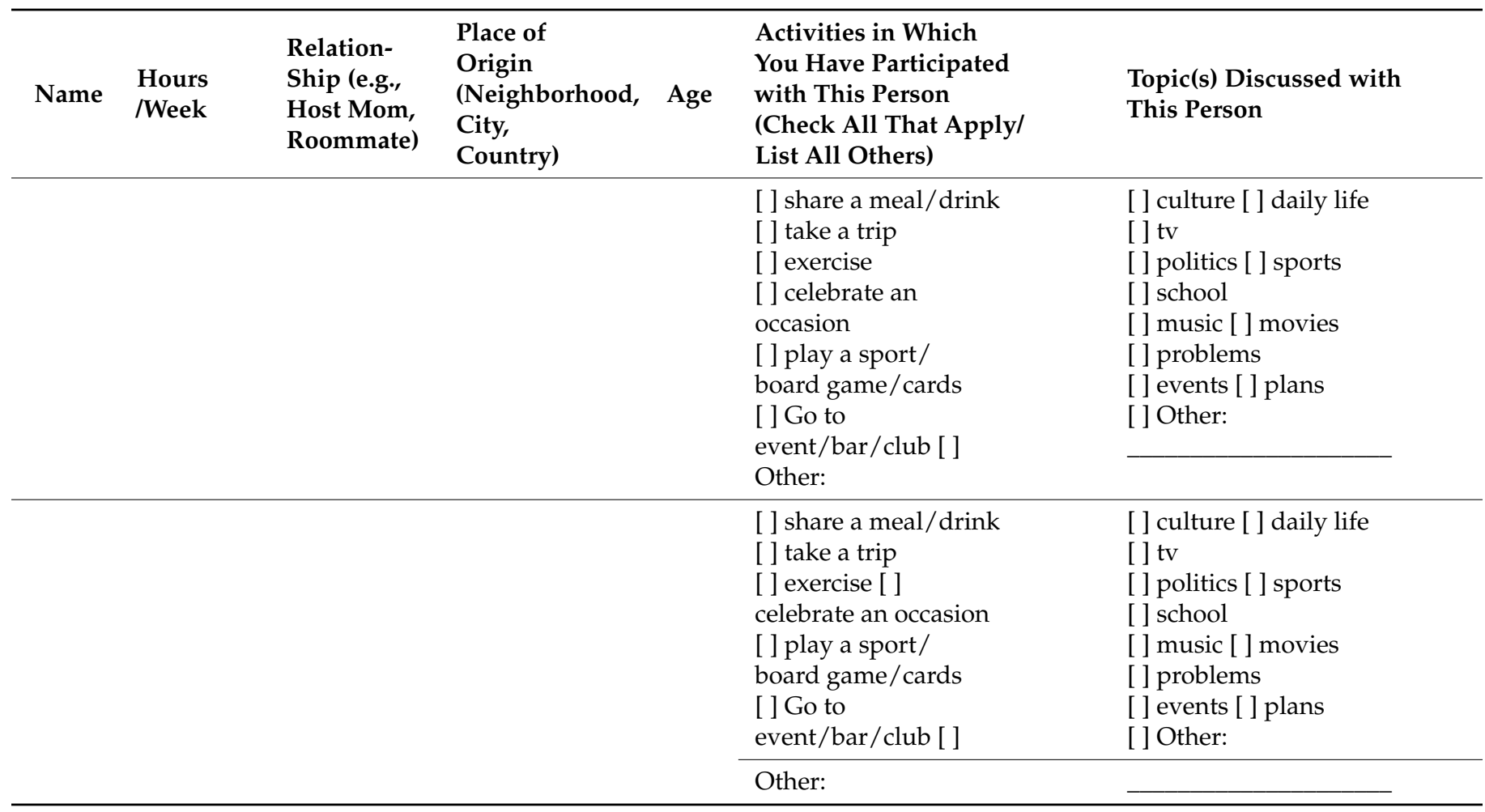


Table A1. Cont.

\begin{tabular}{|c|c|c|c|c|c|c|}
\hline Name & $\begin{array}{l}\text { Hours } \\
\text { /Week }\end{array}$ & $\begin{array}{l}\text { Relation- } \\
\text { Ship (e.g.; } \\
\text { Host Mom, } \\
\text { Roommate) }\end{array}$ & $\begin{array}{l}\text { Place of } \\
\text { Origin } \\
\text { (Neighborhood, } \\
\text { City, } \\
\text { Country) }\end{array}$ & Age & $\begin{array}{l}\text { Activities in Which } \\
\text { You Have Participated } \\
\text { with This Person } \\
\text { (Check All That Apply/ } \\
\text { List All Others) }\end{array}$ & $\begin{array}{l}\text { Topic(s) Discussed with } \\
\text { This Person }\end{array}$ \\
\hline & & & & & [] share a meal/drink & [ ] culture [ ] daily life \\
\hline & & & & & $\begin{array}{l}\text { [ ] take a trip } \\
\text { [ ] exercise [ ] } \\
\text { celebrate an occasion } \\
\text { [ ] play a sport/ } \\
\text { board game/cards } \\
\text { [ ] Go to } \\
\text { event/bar/club [] } \\
\text { Other: }\end{array}$ & $\begin{array}{l}\text { [] tv } \\
\text { [ ] politics [ ] sports } \\
\text { [] school } \\
\text { [ ] music [ ] movies } \\
\text { [ ] problems } \\
\text { [ ] events [] plans } \\
\text { [ ] Other: }\end{array}$ \\
\hline
\end{tabular}

If the native speakers here know each other, which ones and how?

\section{Notes}

1 The conversion of this continuous measure to a discrete one is a limitation of the study. For a discussion of the theoretical and empirical concerns pertaining to this decision, see, for example, Leal (2018).

2 Three learners (Andrea, Emily, and Erin) did not participate in data-collection 2. Given the current study's focus on longitudinal development, a clear weakness of the investigation is that these participants were included in the mixed-effects model (i.e., because observations about their possible change in the use of vos between data-collection 2 and 3 cannot be made and because the inclusion of their usage at data-collection 3 only skews the model).

\section{References}

Bachman, Lyle F. 1990. Fundamental Considerations in Language Testing. New York: Ocford University Press.

Brown, Roger, and Albert Gilman. 1960. The pronouns of power and solidarity. In Style in Language. Edited by Thomas A. Sebeok. Cambridge: MIT Press, pp. 253-76.

Cameron, Robert D. 2012. Why It's Time to Teach Voseo and How to Start. Academic Exchange Quarterly 16: $72-77$.

Collentine, Joseph, and Barbara F. Freed. 2004. Learning context and its effects on second language acquisition: Introduction. Studies in Second Language Acquisition 26: 153-72. [CrossRef]

Escalante, Chelsea. 2018. The Acquisition of a Sociolinguistic Variable While Volunteering Abroad: S-Weakening among L2 and Heritage Speakers in Coastal Ecuador. Unpublished Doctoral dissertation, University of California, Davis, CA, USA.

Geeslin, Kimberly, and Avizia Long. 2014. Sociolinguistics and Second Language Acquisition: Learning to Use language in Context. New York: Routledge.

Geeslin, Kimberly L., Lorenzo J. García-Amaya, Maria Hasler-Barker, Nicolas C. Henriksen, and Jason Killam. 2010. The SLA of Direct Object Pronouns in a Study Abroad Immersion Environment where Use is Variable. In Selected Proceedings of the 12th Hispanic Linguistics Symposium. Edited by Claudia Borgonovo, Manuel Español-Echevarría and Philippe Prévost. Somerville: Cascadilla Proceedings Project, pp. 246-59.

Geeslin, Kimberly L., Lorenzo J. García-Amaya, Maria Hasler-Barker, Nicolas C. Henriksen, and Jason Killam. 2012. The L2 acquisition of variable perfective past-time references in Spanish in an overseas immersion setting. In Selected Proceedings of the 14th Hispanic Linguistics Symposium. Edited by Kimberly Geeslin and Manuel Díaz-Campos. Somerville: Cascadilla Proceedings Project, pp. 197-213.

Geeslin, Kimberly L., Stephan Fafulas, and Matthew Kanwit. 2013. Acquiring geographically-variable norms of use: The case of the present perfect in Mexico and Spain. In Selected Proceedings of the 15th Hispanic Linguistics Symposium. Edited by Chad Howe, Sarah E. Blackwell and Margaret Lubbers Quesada. Somerville: Cascadilla Proceedings Project, pp. 205-20.

George, Angela A. 2013. The Acquisition of Castilian Dialectal Features during a Semester Abroad in Toledo, Spain. Ph.D. dissertation, University of Minnesota, Twin Cities, MN, USA.

George, Angela. 2018. The development of a regional morphosyntactic feature by learners of Spanish in a study abroad setting: The case of vosotros. Hispanic Studies Review 3: 101-25.

Gudmestad, Aarnes, Amanda Edmonds, and Thomas Metzger. 2021. Moving beyond the native-speaker bias in the analysis of variable gender marking. Frontiers in Communication 6: 165. [CrossRef]

Hammond, Robert M. 2001. The Sounds of Spanish: Analysis and Application (with Special Reference to American English). Somerville: Cascadilla Press.

Hoffman-González, Anne C. 2015. Language Use or Non-Use in Study Abroad as an Indicator of community Membership. Ph.D. dissertation, University of Wisconsin, Madison, WI, USA. 
Iwasaki, Noriko. 2010. Style shifts among Japanese learners before and after study abroad in Japan: Becoming active social agents in Japanese. Applied Linguistics 31: 45-71. [CrossRef]

Johnson, Daniel E. 2009. Getting off the Goldvarb standard: Introducing Rbrul for mixed-effects variable rule analysis. Language and Linguistics Compass 3: 359-83. [CrossRef]

Kanwit, Matthew, and Megan Solon. 2013. Acquiring variation in future-time expression abroad in Valencia, Spain and Mérida, Mexico. In Selected Proceedings of the 16th Hispanic Linguistics Symposium. Edited by Jennifer Cabrelli Amaro, Gillian Lord and Ana de Prada Pérez. Somerville: Cascadilla Proceedings Project, pp. 206-21.

Kapovic, Marko. 2007. Fórmulas de tratamiento de dialectos en español; fenómenos de voseo y ustedeo. Hieronymus 1: 65-87.

Kennedy, Kristen M. 2012. What We Don't Learn in the Classroom: The Acquisition of Sociolinguistic Competence during Study Abroad. Ph.D. dissertation, University of California, Davis, CA, USA.

Kennedy Terry, Kristen M. 2017. Contact, context, and collocation: The emergence of sociostylistic variation in L2 French learners during study abroad. Studies in Second Language Acquisition 39: 553-78. [CrossRef]

Kinginger, Celeste. 2008. Language learning in study abroad: Case studies of Americans in France. Modern Language Journal, Special Issue 92: 1-124. [CrossRef]

Labov, William. 1972. Sociolinguistic Patterns. Philadelphia: University of Pennsylvania Press.

Lafford, Barbara A., and Izabela Uscinski. 2014. Study abroad and second language Spanish. In The Handbook of Spanish Second Language Acquisition. Edited by Kimberly Geeslin. Malden: Wiley Blackwell, pp. 386-403.

Leal, Tania. 2018. Data analysis and sampling: Methodological issues concerning proficiency in SLA research. In Critical Reflections on Data in Second Language Acquisition. Edited by Aarnes Gudmestad and Amanda Edmonds. Amsterdan: John Benjamins, pp. 63-88.

LeLoup, Jean W., and Barbara C. Schmidt-Rinehart. 2018. Forms of Address in the Spanish Language Curriculum in the United States: Actualities and Aspirations. Hispania 101: 10-24. [CrossRef]

Li, Xiaoshi. 2014. Variation of subject pronominal expression in L2 Chinese. Studies in Second Language Acquisition 36: 39-68. [CrossRef]

Linford, Bret G. 2016. The Second-Language Development of Dialect-Specific Morpho-Syntactic Variation in SPANISH during Study Abroad (Unpublished Doctoral Dissertation). Bloomington: Indiana University, ProQuest Dissertation Publishing.

Linford, Bret, Sara Zahler, and Melissa Whatley. 2018. Acquisition, study abroad and individual differences: The case of subject pronoun variation in L2 Spanish. Study Abroad Research in Second Language Acquisition and International Education 3: $243-74$.

Lippi-Green, Rosina. 1989. Social network integration and language change in progress in an alpine rural village. Language in Society 18: 213-34. [CrossRef]

Lipski, John. 1994. Latin American Spanish. New York: Longman.

Lybeck, Karen. 2002. Cultural identification and second language pronunciation of Americans in Norway. The Modern Language Journal 86: 174-91. [CrossRef]

Milroy, James, and Lesley Milroy. 1978. Belfast: Change and variation in an urban vernacular. In Sociolinguistic Patterns in British English. Edited by Peter Trudgill. London: Arnold, pp. 19-36.

Regan, Vera, Martin Howard, and Isabelle Lemée. 2009. The Acquisition of Sociolinguistic Competence in a Study Abroad Context. Bristol: Multilingual Matters.

Reynolds-Case, Anne. 2013. The value of short-term study abroad: An increase in students' cultural and pragmatic competency. Foreign Language Annals 46: 311-22. [CrossRef]

Ringer-Hilfinger, Kathryn L. 2013. The Acquisition of Sociolinguistic Variation by Study Abroad Students: The Case of American Students in Madrid. Ph.D. dissertation, University at Albany, State University of New York, Albany, NY, USA.

Salgado-Robles, Francisco. 2011. The Acquisition of Sociolinguistic Variation by Learners of Spanish in a Study Abroad Context. Ph.D. dissertation, University of Florida, Gainesville, FL, USA.

Sax, Kelly J. 2003. Acquisition of Stylistic Variation by American Learners of French. Ph.D. dissertation, Indiana University, Bloomington, IN, USA.

Schreffler, Sandra B. 1994. Second-person singular pronoun options in the speech of Salvadorans in Houston, Texas. Southwest Journal of Linguistics 13: 101-19.

Segalowitz, Norman, Barbara Freed, Joe Collentine, Barbara Lafford, Nicole Lazar, and Manuel Díaz-Campos. 2004. A comparison of Spanish second language acquisition in two different learning contexts: Study abroad and the domestic classroom. Frontiers 10: 1-18. [CrossRef]

Solon, Megan, and Rebecca Pozzi. forthcoming. Language-specific research on second-language sociolingusitics in Spanish. In The Routledge Handbook of Second Language Acquisition and Sociolinguistics. Edited by Kimberly Geeslin. London: Routledge.

Tarone, Elaine E. 1985. Variability in interlanguage use: A study of style-shifting in morphology and syntax. Language Learning 35: 373-403. [CrossRef]

Villareal, Dan. 2014. Connecting Production to judgments: T/V address forms and the L2 identities of intermediate Spanish learners. Journal of Pragmatics 66: 1-14. [CrossRef]

Whatley, Melissa. 2013. The Acquisition of Past Tense Variation by L2 Learners of Spanish in an Abroad Context. In Selected Proceedings of the 16th Hispanic Linguistics Symposium. Edited by Jennifer Cabrelli Amaro, Gillian Lord and Ana de Prada Pérez. Somerville: Cascadilla Proceedings Project, pp. 190-205. 